\title{
Ayurvedic management of unilateral decompressive craniectomy and cranioplasty sequelae - a case
} \section{report}

\begin{abstract}
Stroke is the leading cause of disability and more than half of the stroke survivors will end up severely impaired. The prevalence of stroke in India ranges from 40 to 270 per 100000 population. Like any other surgical procedure, decompressive craniectomy is not without risk and cranioplasty also carries its own risks. Some of the complications arising out of these surgeries may require additional surgery which further increases the risk to the patient for neurological deterioration or death. The present article deals with a diagnosed case of post hemi craniectomy squeal clinically presented as left sided hemiplegia, focal seizures/ myoclonic jerks and irritable mood. The Ayurvedic diagnosis of pakshaghata was made and various panchakarma procedures were implemented along with internal Ayurvedic medicines. Two assessments were taken before and after treatment on NIH-SS (National Institute of Health Stroke Scale) and SS-QOL (Stroke Specific Quality of Life Scale). There is $57.1 \%$ relief on NIH-SS and $83.5 \%$ improvement found on SS-QOL in present case. Ayurvedic panchakarma procedures and medicines were found effective in the management of post hemi craniectomy squeal. The recovery was promising and worth documenting.
\end{abstract}

Volume 7 Issue 5 - 2017

\section{Prasad Mamidi, Kshama Gupta}

Department of Kayachikitsa, Parul Institute of Ayurveda, India

Correspondence: Prasad Mamidi, Dept of Kayachikitsa, Parul Institute of Ayurveda, Parul University, Vadodara, Gujarat, India, Tel 7567222856,Email drprasadmamidi@gmail.com

Received: April 25, 2017| Published: May I5, 2017

Keywords: hemi craniectom, decompressive craniectomy, stroke, ayurveda, pakshaghata, focal seizures

\section{Introduction}

According to WHO (world health organization) publication, 'Gloabal health risks: Mortality and burden of disease attributable to selected major risks', cardio-vascular disease accounts for $30 \%$ of deaths globally. Out of these, 5.7 million deaths (i.e. $9.7 \%$ of all deaths) are caused by stroke. Stroke is the leading cause of disability and more than half of the stroke survivors will end up severely impaired. The prevalence of stroke in India ranges from 40 to 270 per 100000 populations. ${ }^{2}$ Decompressive craniectomy (DC) has been used in the management of raised intra cranial pressure (ICP) or herniation syndrome. A large portion of the skull is removed to allow swollen brain to herniate outwards in DC. Cranioplsaty is another surgical procedure follows DC in which the autologous skull or synthetic material or bio-ceramics are used to repair the skull defect caused by DC. DC is not without risk like any other surgical procedure and cranioplasty also carries its own risks. Some of the complications arising out of these surgeries may require additional surgery which further increases the risk to the patient for neurological deterioration or death. ${ }^{3}$

Here we are reporting a case of ischemic stroke, has undergone DC followed by cranioplasty and has been suffering with focal seizures, non-functioning left upper limb with irritable mood. The patient came to our care for an Ayurvedic management for his condition. Written and informed consent was obtained from the patient for the publication of the present case report.

\section{Case description}

A 57year aged old gentleman came to our care (11.07.2016), with the complaints of left sided weakness, pedal edema (left leg), myoclonic jerks / focal seizures (involving left upper and lower limb), irritability / aggressive mood, drowsiness, frequent urinary tract infections, gaze preference to the right, hypertension and dyslipidemia. This gentleman has suffered with an ischemic stroke
(May 2014) and undergone right decompressive craniectomy for right middle cerebral artery (MCA) infarction (May 2014) followed by right side titanium cranioplasty (December 2014). He has made progress since then. He is left with a non functioning upper limb but able to manage this well. He mainly resides in a wheel chair, however does mobilize with a tripod / quad stick (Figure 1). He has reported recurrent urinary tract infections and experiences poor flow, terminal dribbling, penile pain and dysuria. He has developed seizures followed by surgery which comes without warning, four times a week and causes his left sided limbs to shake. He is fully awake during the seizure episodes and is confused afterwards. He also had abdominal pain, bloating / discomfort. He has been taking antiepileptics, anti-hypertensive, thrombolytics, NSAID's and laxatives. $\mathrm{He}$ has not satisfied with the western medicines and management for his condition and came to our care for Ayurvedic treatment with the hope of getting functional recovery of left upper and lower limb. Hematological, biochemical investigation reports were within normal limits (26 \& 30.08.2016) (Table 1). No past history of head injury, diabetes, cardiac pathology and any major medical illness found. No positive family history of stroke, diabetes, hypertension, dyslipidemia and cardio-vascular pathology found. Patient has undergone surgery for varicose veins of right lower limb. At the time of examination patient's vital functions were normal and patient was drowsy and responded to vocal commands. Tendon reflexes were exaggerated; muscle tone was increased in left upper and lower limb with positive babinski. Clinical examination revealed a soft, non tender abdomen with no palpable bladder. DRE (digital rectal examination) revealed a $30 \mathrm{gm}$ benign feeling prostate. Pitting edema was found in left lower limb. Patient used to smoke, takes alcohol and not having allergy to any drug or food item.

\section{Diagnosis, assessment \& treatment}

Patient got right MCA infarction (ischemic stroke) and undergone right decompressive craniectomy followed by elective cranioplasty. 
CT brain (18.05.2014) revealed evidence of extensive thrombus involving right MCA and right internal carotid artery (ICA) (Table 1). Total two assessments were carried out. Baseline / initial assessment was taken on the first day of starting Ayurvedic treatment (11.07.2016) and second assessment was carried out at the time of discharge (21.03.2017). A criterion of assessment was based on the scorings of NIH-SS (National Institute of Health - Stroke Scale) ${ }^{4}$ and SS-QOL (Stroke Specific Quality of Life Scale). ${ }^{5}$ Ayurvedic diagnosis of 'Pakshaghata (vama parshwa)' is made and treated accordingly.

Table I Investigation reports

\begin{tabular}{|c|c|c|}
\hline Date & Name of investigation & Report \\
\hline \multirow[t]{3}{*}{05.11 .2013} & MRI scan of Lumbo-sacral spine & Showed disc bulge at L4 - L5 and L5 - SI \\
\hline & CT Brain & $\begin{array}{l}\text { Extensive thrombus within } \\
\text { the right internal carotid } \\
\text { artery (ICA) and right } \\
\text { middle cerebral artery (MCA) } \\
\text { commencing } 1.6 \mathrm{~cm} \text { from } \\
\text { the right common carotid artery bifurcation. }\end{array}$ \\
\hline & & $\begin{array}{l}\text { There has been evolution of } \\
\text { the previously seen right }\end{array}$ \\
\hline \multirow[t]{2}{*}{$18.05 .20 \mid 4$} & & $\begin{array}{l}\text { MCA territory infarction with } \\
\text { hypodensity now seen in the } \\
\text { entire MCA territory with } \\
\text { a significant associated }\end{array}$ \\
\hline & Repeat CT Brain after few days & $\begin{array}{l}\text { increase in swelling } \\
\text { throughout the supratentorial } \\
\text { brain, new midline shift to } \\
\text { the left of } 10 \mathrm{~mm} \text {, generalized } \\
\text { sulcal effacement and } \\
\text { effacement of the right } \\
\text { lateral ventricle. }\end{array}$ \\
\hline $15.07 .20 \mid 5$ & X-Ray of left shoulder & Normal report \\
\hline 23.07.2015 & USG Abdomen & $\begin{array}{l}\text { Moderate prostatic hypertrophy } \\
\text { and mild right renal } \\
\text { pelvis dilatation seen. }\end{array}$ \\
\hline 08.10 .2015 & Barium meal study & Normal report. \\
\hline \multirow[t]{2}{*}{31.12 .2015} & Flexible cystoscopy & Normal report. \\
\hline & Gastroscopy & Mild duodenitis (erythematous); \\
\hline 09.04 .2016 & Colonoscopy & $\begin{array}{l}\text { Few scattered diverticula in } \\
\text { the sigmoid colon which denotes, } \\
\text { 'sigmoid diverticular disease'. }\end{array}$ \\
\hline \multirow{3}{*}{26.08 .2016} & Urine for culture and sensitivity & $\begin{array}{l}\text { No organism isolated after } 48 \text { hours } \\
\text { of aerobic incubation; }\end{array}$ \\
\hline & Liver function tests & Normal report; \\
\hline & Serum creatinine & I.3mg / dl; \\
\hline 30.08 .2016 & $\begin{array}{l}\text { Hematological investigations like } \\
\text { hemoglobin, } \\
\text { WBC count, RBC count, } \\
\text { Platelet count etc; }\end{array}$ & Within normal range. \\
\hline \multirow[t]{5}{*}{10.01 .2017} & $\begin{array}{l}\text { Prothrombin time (PT), } \\
\text { Activated partial thromboplastin } \\
\text { time (APTT), } \\
\text { liver function tests, } \\
\text { lipid profile and routine } \\
\text { hematological investigations; }\end{array}$ & Within normal range. \\
\hline & Serum urea & $56 \mathrm{mg} / \mathrm{dl}$ \\
\hline & Serum cholesterol & $223 \mathrm{mg} / \mathrm{dl}$ \\
\hline & Serum triglycerides & $92 \mathrm{mg} / \mathrm{dl}$ \\
\hline & Serum HDL & $58 \mathrm{mg} / \mathrm{dl}$ \\
\hline \multirow{5}{*}{01.03 .2017} & Serum LDL & l $46.6 \mathrm{mg} / \mathrm{dl}$ \\
\hline & Serum VLDL & $18.4 \mathrm{mg} / \mathrm{dl}$ \\
\hline & Cholesterol / HDL ration & 3.84 \\
\hline & Serum LDL / HDL cholesterol & 2.52 \\
\hline & ESR & $32 \mathrm{~mm}$ in I hour \\
\hline
\end{tabular}

Initially line of treatment was planned to control focal seizures, myoclonic jerks, to improve mood, to reduce urinary tract infection, to reduce pedal edema and to bring stability in general condition of the patient (from 11.07.2016 to 14.09.2016). Later allopathic medicines which the patient has been consuming like, anti-epileptics, anti-hypertensive's, thrombolytics, NSAID's and laxatives were withdrawn and replaced by Ayurvedic internal medicines (from 24.01.2017 to 21.03.2017) (Table 2). 
Table Continued...

\begin{tabular}{lll}
\hline Date & Name of investigation & Report \\
\hline & Serum cholesterol & $223 \mathrm{mg} / \mathrm{dl}$ \\
& Serum triglycerides & $1 \mathrm{I} 5 \mathrm{mg} / \mathrm{dl}$ \\
& Serum HDL & $56.5 \mathrm{mg} / \mathrm{dl}$ \\
& Serum LDL & $143.5 \mathrm{mg} / \mathrm{dl}$ \\
& Serum VLDL & $23 \mathrm{mg} / \mathrm{dl}$ \\
& Cholesterol / HDL ration & 3.94 \\
& Serum LDL / HDL cholesterol & 2.53 \\
\hline
\end{tabular}

Table 2 Intervention

\begin{tabular}{|c|c|c|c|c|}
\hline Duration & Medicine & Dose & Frequency & Anupaana \\
\hline 11.07 .2016 to & I.Abhayarishta & $20 \mathrm{ml}$ & twice a day, after food & with equal quantity of water \\
\hline 18.08 .2016 & 2. Neeri tablets & $500 \mathrm{mg}$ & twice a day, after food & with water \\
\hline 19.08 .2016 to & I. Neeri tablets & $500 \mathrm{mg}$ & twice a day, after food & with water \\
\hline $14.09 .20 \mid 6$ & 2. Palsineuron capsules & $\operatorname{lgm}$ & twice a day, after food & with water \\
\hline \multirow[t]{2}{*}{$\begin{array}{l}09.01 .2017 \text { to } \\
23.01 .2017\end{array}$} & I. Palsineuron capsules & Igm & twice a day, after food & with water \\
\hline & I. Rasa rajeshwara ras & $250 \mathrm{mg}$ & twice a day, after food & with water \\
\hline \multirow{5}{*}{$\begin{array}{l}24.01 .2017 \text { to } \\
28.02 .2017\end{array}$} & 2. Prasaaranyadi kwatha & $15 \mathrm{ml}$ & twice a day, before food & with $45 \mathrm{ml}$ of water \\
\hline & 3. Kalyana avaleha choornam & $3 g m$ & twice a day, after food & with honey \\
\hline & 4. Cardocalm tablets & $500 \mathrm{mg}$ & twice a day, after food & with water \\
\hline & 5. Maha yogaraja guggulu & $500 \mathrm{mg}$ & twice a day, after food & with water \\
\hline & I. Sheetaprabha tablets & $500 \mathrm{mg}$ & twice a day, after food & with water \\
\hline 01.03 .2017 & 2.Varanadi kwatha & $15 \mathrm{ml}$ & twice a day, before food & with $45 \mathrm{ml}$ of water \\
\hline to & 3. Dhanwantaram IOI avarti sofgels & 2 sofgels & twice a day, after food & with water \\
\hline \multirow[t]{2}{*}{21.03 .2017} & 4. Cardocalm tablets & $500 \mathrm{mg}$ & twice a day, after food & with water \\
\hline & 5. Maha yogaraja guggulu & $500 \mathrm{mg}$ & twice a day, after food & with water \\
\hline
\end{tabular}

\section{Panchakarma intervention}

\subsubsection{6 to \\ 02.08 .2016 \& \\ 19.08.2016 to \\ $31.08 .2016 \&$ \\ 09.09 .2016 to \\ 14.09.2016}

03.08 .2016 to

18.08.2016

(Kaala vasti schedule)

\&

01.09 .2016 to

08.09.2016

(Yoga vasti schedule)

09.01 .2017 to

23.01.2017

24.01 .2017 to

31.01.2017

(Yoga vasti schedule)

$\&$

08.02.2017 to

23.02.2017

(Kaala vasti schedule)

01.02 .2017 to

07.02 .2017

24.02 .2017 to

28.02.2017

01.03 .2017 to

21.03 .2017
Udwartana with Yava kola kuluthadi choorna

I. Patra pottali pinda sweda with Prasaranyadi tailam

2. Bashpa sweda (in steam chamber)

3. Niruha vasti

(A. Saindhava lavana - $6 \mathrm{gm}$

B. Madhu - $100 \mathrm{ml}$

C. Sindhuvara eranda tailam - $100 \mathrm{ml}$

D. Satapushpa \& Hinguvachadi kalkam - 25 gm

E. Dashamoola \& Rasna saptaka kwatha - $400 \mathrm{ml}$

F. Gomutra arka - $100 \mathrm{ml}$

G. Kalyanaka ksharam - 3 gm)

(or)

4. Anuvasana vasti with Sahacharadi tailam $-80 \mathrm{ml}$

I. Udwartana with Yava kola kuluthadi choorna

2. Nasya karma with Dhanwantaram IOI avarti tailam

I. Patra pottali pinda sweda with Kottamchukkadi kuzhambu

2. Bashpa sweda (in steam chamber)

3. Niruha vasti

(A. Saindhava lavana - $6 \mathrm{gm}$

B. Madhu - $150 \mathrm{ml}$

C.Vastyamayantaka ghritam - $100 \mathrm{ml}$

D. Satapushpa kalkam - $25 \mathrm{gm}$

E.Varanadi kwatha - $400 \mathrm{ml}$ )

(or)

4. Anuvasana vasti with Pippalyadi anuvasana tailam - $80 \mathrm{ml}$

Takra dhaara

I. Udwartana with Yava kola kuluthadi choorna

2. Shiro pichu with Ksheera bala tailam

I. Patra pottali pinda sweda with Dhanwantaram kuzhambu

2. Bashpa sweda (in steam chamber) 


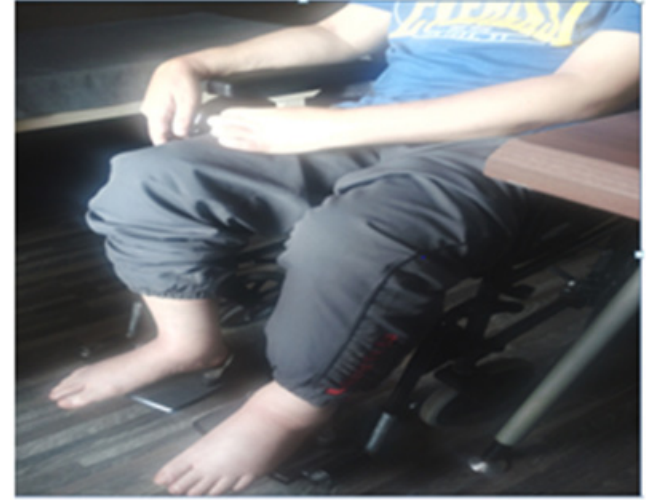

Figure I Left sided hemipegia with pitting edema at left foot.

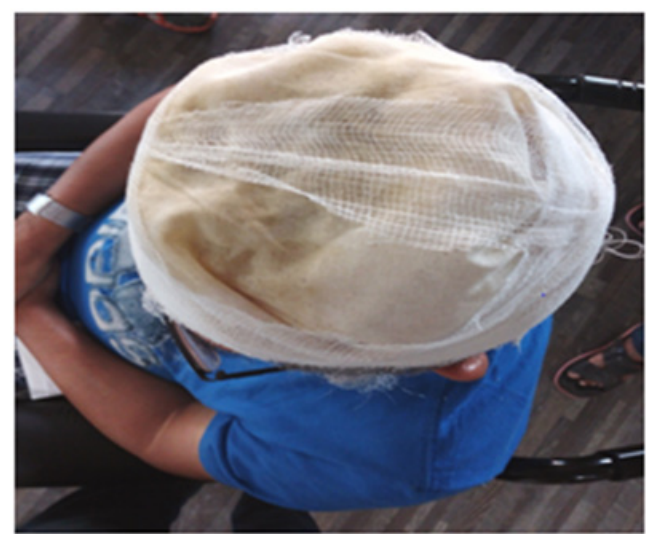

Figure 2 Shiro pichu.

\section{Discussion}

DC is an effective means of controlling elevated ICP and it is also life saving; while the procedure is technically straight forward, it places the patient at risk for many non-trivial complications, which can negatively impact outcome. Complications of DC are mainly of three types, hemorrhagic, infectious/inflammatory and disturbances of the cerebrospinal fluid (CSF) compartment. Complications which are associated with cranioplasty also fell under similar major types with additional complications relating to the bone flap. ${ }^{3}$

Pakshaghata is a vata vyadhi (disease caused by vata dosha) and can be correlated with hemiplegia/stroke. Panchakarma (five major cleansing procedures) procedures like Udwartana (herbal powder massage), Vasti (medicated enema), Nasya (nasal medication) and virechana (therapeutic purgation) were found to be beneficial in the management of pakshaghata. Previous study has reported significant relief on NIH-SS and on SS-QOL in stroke patients with integrated approach (conventional modern medicine with Ayurveda and physiotherapy) ${ }^{6,7}$ The present case report deals with the efficacy of an Ayurvedic treatment in the management of post hemi craniectomy complications.

Udwartana procedure was selected initially to reduce the pedal edema and to achieve 'niraamavastha'. Abhayarishta was used to relieve constipation and laxatives were stopped. Neeri tablets, sheetaprabha tablets were prescribed to tackle urinary tract infection whenever required. Palnsineuron capsules were prescribed for left shoulder pain and pain at left thigh (NSAID's were stopped). Cardocalm tablets were used to control hypertension (after stopping anti-hypertensives). Maha yogaraja guggulu, Rasa rajeshwara ras, prasaranyadi kwatha and Dhanwantaram 101 avarti sofgels were prescribed for vata shamana (to pacify vata dosha) (Table 2).

Panchakarma procedures like vasti (yoga vasti and kaala vasti schedules), nasya, patra pottali pinda sweda (massage with the bolus prepared by medicinal leaves and herbal powders), sarvanga abhyanaga (full body oil massage), bashpa sweda (steam in steam chamber) and udwartana were implemented according to the requirement and condition of the patient. Takra dhara (pouring medicated butter milk over forehead) and shiro pichu (keeping cotton over the head which is dipped in medicated oil) (Figure 2) were implemented to tackle aggressiveness, sleeplessness and irritability. Patient has also received physiotherapy treatment along with panchakarma wherever feasible (Table 2).

On NIH SS, good relief was noticed in left upper and lower extremity function. Baseline score (11.07.2016) on NIH-SS was 7 which was improved to 3 at the time of second assessment (21.03.2017). There was $57.1 \%$ of improvement was found on NIHSS. On SS-QOL, maximum relief was noticed in items like, energy levels, mobility, personality, mood and upper extremity function. The baseline score on SS-QOL during initial assessment was '91' (11.07.2016) which is improved to ' 167 ' during second assessment (21.03.2017) (which denotes $83.5 \%$ relief). Patient was able to climb the stairs without support at the time of discharge and able to do his routine works with ease. Pedal edema got reduced and constipation relieved. Left shoulder pain and left thigh pain were diminished, range of movement were improved in left upper and lower limb with reduced stiffness. Myoclonic jerks, focal seizures got reduced (frequency of once a week) with improved mood and quality of life. The recovery was promising and worth documenting.

\section{Conclusion}

Udwartana is effective in reducing the pedal edema in present case. Various panchakarma procedures like vasti, nasya, patra pottali pinda sweda, bashpa sweda are seems to be beneficial in improving the functioning / mobility in present case. Shiro pichu and takra dhara are effective in the management of aggressiveness / irritable mood and sleeplessness in present case. There is $57.1 \%$ relief on NIH-SS and $83.5 \%$ improvement found on SS-QOL in present case. Ayurvedic treatment seems to be promising in the management of post hemi craniectomy squeal.

\section{Acknowledgments}

None.

\section{Conflicts of interest}

Author declares there are no conflicts of interest.

\section{Funding}

None.

\section{References}

1. Gunaratne PS, Wijeyaratne CN, Chandrasiri P, et al. An outbreak of Aspergillus meningitis following spinal anaesthesia for caesarean section in Sri Lanka: a post-tsunami effect? Ceylon Med J. 2011;51(4):137-142.

2. Pandian JD, Jaison A, Deepak SS, et al. Public Awareness of Warning Symptoms, Risk Factors, and Treatment of Stroke in Northwest India. Stroke. 2005;36(3):644-648.

3. Kurland DB, Khaladj-Ghom A, Stokum JA, $\mathrm{t}$ al. Complications associated with decompressive craniectomy: A systematic review. Neurocrit Care .23(2):292-304. 
4. Brott T, Adams HP, Olinger CP, et al. Measurement of acute cerebral infarction: A clinical examination scale. Stroke. 1989;20(7):864-870.

5. Williams LS, Weinberger M, Harris LE, et al. Development of a stroke specific quality of life scale. Stroke. 1999;30(7):1362-1369.

6. Prasad Mamidi, Kshama Gupta. Role of stroke unit care with panchakarma in the management of stroke: An observational case series. In J Res Ayurveda Pharm. 2014;5(3):252-255.
7. Prasad Mamidi, Kshama Gupta. Ayurvedic management of stroke with special reference to left temporo-parietal lobe gliosis: A case report. $J$ Pharm Sci Innov. 2014;3(6):536-538. 